\title{
Traditional Marriage Customs in Maharjan Community of Lalitpur District: An Ethnographic Exploration
}

Ganga K. C. (Ph. D.)*

\begin{abstract}
The paper investigates how and why the traditional forms of marriage systems are sustained. This paper describes the marriage practices among Maharjan, and explains how it is anthropologically interesting. The main purpose of this research paper is to examine traditional marriage practices of the Maharjan people as well as the procedures from beginning to end of the marriage. Nepal is a multiethnic and multicultural country along with ecological variation and hidden ethno history. Most of them have their specific language, religion, cultural practices, food habits, festivals, rites and rituals. Among the 59 indigenous ethnic groups of Nepal, the Newars are one of them. Among the different groups of Newar, Maharjan is one sub-group. The present study is ardent to the Maharjan people of Ghachhe Tole of Patan in general and their practice of traditional marriage in particular. This study has been steered by retaining both exploratory cum descriptive research design using the qualitative data. The data of the present study is based on primary as well as secondary sources. In this exploration more detailed account of the traditional marriage practice and processes amongst the Maharjan people is presented in an intricate manner. The entire procedures of the Maharjan marriage, and their innumerable rites and rituals are explained clearly.
\end{abstract}

Key words: Traditional, marriage, customs, guthi, lami \& kinship.

\section{Introduction}

Nepal is multi ethnic and multi-cultural country. The ethnic diversity and cultural plurality, followed by ecological variation and hidden ethno history of the nation benevolences Nepal, like many other multiethnic nations in the world. As noted, there are more than 103 ethnic groups in Nepal among which 63 are well organized and registered at the profile

*Dr. K.C. is an Associate Professor at the Department of Anthropology, Patan Multiple Campus, TU, Lalitpur, Nepal. Email: gangakc1968@gmail.com 
of Nepal Federation of Indigenous Nationalities (Nepal Aadibasi Janajati Mahasangh, 2053). Most of them have their specific language, religion and cultural practices which holds their identity. They have typical food habits, festivals, folk dances and folk songs, rites and rituals. Among the above-mentioned 63 indigenous ethnic groups, the Newars are one of them in Nepal.

The Newars are one of the most significant ethnic groups of Nepal. People of Newar community are scattered all over the country. It is believed that the word Newar is came from the word- 'Nepal'. Bista (1996) enlightens that the term 'Newar' embraces people of both Mongoloid and Mediterranean physical types who speak both Nepali and Indo-Aryan language, and Newari, a Tibeto-Burman language that includes some half a dozen dialects.

In this respect Bista (1996) further argues that because of the complexities in the composition of Newar society, scholars in the past have developed various interesting theories about their origins. The Newari language, although greatly influenced by Sanskrit, is still distinctly a Tibeto-Burman tongue. Although it uses Devnagari script today, it does have its own script as well. Nepali (1965) argued that Newars might have originated in south India, with ties or distinct similarities to a Hindu community on the Malabar Coast called the Nair, or Nayar. In this regard Haimendorf (1957) conclude, "The bulk of the Newar people had settled in the Nepal valley since prehistoric times". Regmi (1952), however, speculates that the early Newars may have an ancestry connected with both the Kiranti and the Lichchhavis, historic ruler of the Nepal valley.

The Newars are one of the indigenous inhabitants of the Kathmandu Valley. They are found in great numbers in every towns and village in the surrounding districts and in all regions of the country. Traditionally they are engaged as small shopkeepers, big merchants, farmers, craftsmen and so on. Among the Newars various sub-groups (approximately 115) are found depending on their socioeconomic status, occupation and religion, which includes from the lowest to the highest prominence, from sweeper to priest and both Hindu and Buddhist. The Lichchhavi king Jayasthiti Malla, according to the occupations stratified the caste hierarchy of Newars. Rosser (1966), Shakya (2000), Toffin (2007) and Gellner (1992) wrote about Newars and their marriage customs, society and rituals. The notions of these scholars provide a detail account about Newars. The Newars are one of the unique and interesting people, and one of the oldest one groups in Nepal, Kathmandu valley. Today the Newars are actively redefining themselves in Nepal's multi ethnic polity. Among the Newars, Maharjan is one of the most significant sub-group, is studied in this research.

Marriage is one of the most important social institutions for living a sound and happy family life. It unites the two opposite sexes in order to satisfy their biological and 
social needs. Marriage has its own heritage and considered essential all over the world. This fundamental institution has preserved the human race and made the existence of civilization possible. In every human society, marriage is imperative due to the religious and psychosocial constraints or obligations. Lowie (1961) explains that marriage and family are complementary concepts: marriage is an institution and family is the association that embodies the institution. Both are rooted in sex, but cannot be understood merely from the point of view of sexual relations. The latter is a matter of sheer biology; therefore marriage and family is the cultural super structure upon a biological foundation. In fact, family and marriage are complimentary to each other. As Gillin and Gillin believed, "Marriage is a socially approved way of establishing a family of procreation" quoted by Rao (2004). Marriage is an institution of society, which can have very different implications in different cultures. Purpose, function and forms of marriage may differ from one society to another, but it is present everywhere as an institution.

Different types of marriage systems are practiced in various societies. Various anthropologists and scholars define marriage differently because of the controversial nature of it's meaning in different societies and social contexts. Even though it refers to the human mating relationships in general, it takes into consideration different factors such as sex and procreation, the issues of legitimacy of children and other relevant factors. It has been understood that the meaning and emphasis of marriage differs in different societies. The institution of marriage exists in almost all the societies irrespective of their development and time. The concept of marriage may be understood better by considering the general and universal characteristics observed in almost all parts of the world. These rules are of important forms: regulation by kinship or genealogical relationship and second one is regulation by some form of social mechanism consisting of clans or similar social groups. These rules also prohibit or enjoy certain unions.

Moreover in Nepal where marriage and bond between individuals is taken as a family affair and given great importance, divorce is not approved of. Although divorce is allowed in Hinduism but is considered as the most unpleasant affair of life and society considers it to be a taboo and it is discouraged. This can be considered as the main reason for divorce rate being low in Nepal.

\section{Objectives}

The overall objective of this research was to study the traditional marriage customs of Maharjan community as well as marriage procedures from beginning to the end. The present study is devoted to the Maharjan people of Ghachhe Tole of Lalitpur sub-metropolitan city, ward no. 9 in general and their practice of traditional marriage in particular. The Maharjan 
sub-group of this Tole is very rich in its culture and their language.

\section{Methodology}

This study has been conducted by employing both exploratory and descriptive research design. For this study, only qualitative data are used, collected from the study area by using various significant anthropological methods. The primary data were collected from the field and are based on ethnography methods- interviews with the elder people of the Maharjan community, head and other members of the Maharjan Guthi, old women of Maharjan community, ritual performers and educated persons of the community. Major rituals of the marriage were also observed. The data of the present research is based on published articles and books as secondary source.

\section{Discussion and Findings}

\section{Marriage Processes and Customs}

Similar to Hindu's philosophy the Maharjans also strongly believe in the concept that the marriage is a continuation of a relationship between two people of opposite sex. And between the two families that are expected to interact, develop the bondage and fulfill their responsibilities towards their parents and ancestors, by continuing the natural process of procreation, caring for their offspring, and continuing god's creation. The principal objective of marriage is mainly, procreation of children to establish and continue the family and also marriage provides the license of sexual pleasure to an individual. The same situation is applied among the Maharjan people also. For the performance of marriage, Maharjan community have to go through the various rituals in different stages of marriage process that are discussed below.

The Maharjan marriage composes of various functions with symbolic meanings. Maharjan people prefer the patrilocal and monogamous marriage as their strict traditional practice. The parents of boy and girl traditionally arrange the marriage for their sons and daughters. Because of modernization and imitation, the trend of the girls and boys choosing their life partners, is increasing day by day. Marriage by elopement is more commonly practiced by new young generations within same or different caste groups.

All the Newars practice the symbolically arranged marriage of their daughters with the $\mathrm{Bel}$ fruit, which considered very sacred and offered to Lord Shiva, before they marry a man. It is usually done at the age of five to nine years or before the girl's puberty. Since it is the general belief of Hindu and Buddhist Newar communities that a proper marriage with full ritual rites can be held only once in a lifetime, her subsequent marriages, if any are 
considered of only secondary importance. Although a Newar girl marries a boy later on with almost the full ritual, the girl retains her marital status with the Bel (aegle marmelos) fruit. After Bel Vivah (Ihi), when the girl becomes young, real marriage is performed.

There are various steps in the course of completion of marriage among Maharjan culture and community. In the traditional arranged marriage, the parents of boy first; select a suitable girl for their home and son. Then they appoint one of their friends or relatives as a Lami (mediator- who is familiar with both side) to carry the proposal back and forth. Usually the Lami is a woman who acts as a mediator. In the Newar community, a mediator is known as Lami, who plays an important role in establishing matrimonial relationship between the two sides (girl and boy) who are appreciated by the society and all members. Anybody can be a Lami within the community and surroundings. He or she may be relatives, neighbors or friends etc. Any relative or friend can mediate but in some communities there are people who have been prized as Lami as for a long time and have good knowledge about marriageable boys and girls in the community. Both woman and man can act as Lami. The Lami gives information about the proposed boy to the parents of the girl and her family. After all inquiries about boy and his family if the girl's parents agree to give their daughter to the proposed boy they inform the Lami. After the initial inquiries Lami asks for Jata (horoscope) of the girl. If they are satisfied with the boy they send Jata of the girl to the boy's parents through the Lami. If both Jata match the boy's side formally sends the message of acceptance to the girl's side through the Lami. Usually the parents of the boy formally go to the girl's family and give them the particulars of their son and request the girl's parents for their daughter's marriage with their son. If both sides are satisfied with each other the marriage proposal is accepted and fixed at the time. Then they fix the date of next ritual called-Lakha Biyegu.

\section{Lakha Biyegu}

Lakha Biyegu is the first ritual of marriage. It signifies good luck for the bride. Once it is agreed that both Jata are compatible, several presentations of small gifts of food items, sweets, areca nuts and fruits are sent to the girl's parents by the boy's side. The marriage is confirmed when the girl's side accepts the presents sent by the boy's side. In Lakha Biyegu ceremony, the groom's side sends the areca nuts to the bride's side, which signifies the ritual of engagement. This ritual is performed few days, few months or few years before marriage. The boy's side gives areca nuts of big size, Chaku (cooked raw sugar)-200 grams, one-rupee coin and small amount of vermillion powder in an open bowl called Lampicha made up of bamboo stick, to the girl's side. For this ritual boy's mother and Lami go to the girl's home with ritually well-decorated Sukunda (ritual brass 
lamp with water pitcher). After receiving the Lakha, Lami and groom's mother is treated by feast according to Newari custom.

According to the traditional marriage custom, groom's party sends 28 kilograms and 800 grams of Lakhamari (special kind of sweet bread) as the Lakha few days before the marriage. These Lakhamari are specially made for the marriage ritual. Different shaped and sized Lakhamaris i.e. Aith $a$ and Jo Pastas are distributed among the agnates and cognates of the bride's parents. The size and shape depends on the nearness of the relationships of the Agnates and cognates of the bride's family. One piece of coin should also send with Lakhamari. The relatives, who receive the Lakhamari, gift the bride with respect to the amount they receive.

\section{Painaja (farewell) Ritual}

Painaja is farewell ritual of the girl who is going to be married. The girl is not only the member of the family where she is born but also of all of her kins. Therefore, one day before the proper wedding day, her maternal uncle and aunty invites the bride for meal. By tradition aunty of the bride lights the light in the Sukunda and offers different auspicious materials to the Lord Ganesh then she puts Tika (mixture of rice, curd and vermillion powder) in the bride's forehead as her blessings and gives Sagun to the bride as gifts. Then the bride has dinner with the family.

\section{Paju ku Ritual}

This is another important ritual of traditional marriage of Maharjan and performed one day before the proper wedding day in the bride's house. The bridegroom's Paju and Lami (maternal uncle and mediator) go to the bride's house with Paju Ku. The bride's party offers Tucha (ritual food including- chhoila or Bhutan of buff, including egg, beaten rice, wine and Thon) to them that they enjoy together.

\section{Payanbiya Bhoya}

Two days before the proper wedding day, both fathers perform a ritual called Shraddhaworship of ancestors with the help of their own priest respectively. Next day they perform Mu Bhoya (main party) of the marriage. This is also known as Payanbiya Bhoya, in which bride's family invites all of their relatives and friends. This feast is served according to Newari culture, which includes five stages with different food items called Suku Bhoya.

\section{Hinu Bhoya}

In this party other guests who belong to their kin like Phuki (elder brother), Kija (younger brother) are invited. In the Jyapu society Phukis are those peoples who worship same 
Diga Dyah (kin deity) together in same place. If any member of the group is performing any ritual, all the members of Phuki and their family members should attend the function like birth and death ritual. In marriage ceremony Phuki members are invited for the Hinu Bhoya. This ritual is performed after the main feast of the marriage and before Khoyague-Kaya-gue. In Hinu Bhoya bride should give four areca nuts to Hinu Phuki. After receiving areca nuts Hinu Phuki should give some money to the bride as blessings. After this the bride is out of the Dewali Guthi forever.

\section{Bhamcha ka wanegu (La-So-Wanegu)}

La-So-Wanegu is marriage procession. The groom's procession party brings $K u$ for the bride's side. Nhya kuli (a pair of fish in clay pot) and Dunu Kuli (half liter of milk in clay pot), one set of dress for bride, Sukunda, Musya Pwu (panas batti), khwata (a traditional brass tray used in special occasion), curd, Twya Sway and Gnna Kera Swa. Nhyu Kuli is a symbolical act of return of bride's life to her parents. Duru Kuli is a symbolic ritual of payment of girl's mother's milk.

When the groom's procession reaches to the house of the bride, bride's party welcomes them in a proper way as per their custom. Then the bride's father welcomes the Lami, moher and father of groom, Thakalinaku and other family members who are in procession, in their house. The procession members then take their seat in the courtyard or pavilion, which is made for the guests. A group of people starts to play Baja (musical instrument) with Newari songs. Then the guests enjoy the food.

\section{The Proper Wedding Ritual}

The proper wedding ritual is the most significant part of the whole ceremony. The parents of the bride give their well-nurtured daughter to the family of the groom through the matrimonial alliance with the groom. This is considered the greatest donation cum gift in one's life for fulfillment of god's purpose in every living being. This ritual is similar to the Hindu beliefs of Kanyadan (donation of virgin daughter). According to the Hindu beliefs, the word Kanyadan also has a great significance. This indicates that the parents have successfully nurtured their daughter as a virgin and to be devoted physically, emotionally, and spiritually to her spouse and the family. For the most awaited moment of proper wedding ritual, the bride is well dressed in proper wedding costumes or in imitated ways. The deities are worshipped then the proper wedding rituals can start.

\section{Thayaebhu Nakegu}

After dinner the proper wedding ritual starts. For the proper wedding ritual a large bronze plate, which is well decorated with different food varieties for feeding the bride, is 
made ready. The food prepared for Thayaebhu Nakegu is also called Chaurasi byanjan (includes eighty four dishes). First of all, these all food items are offered to god then given to the bride. The rest of the food is thrown at the Chhwasa (crossroads). It is the place to throw unclean food to satisfy the Ajima (deity). If the deity is unsatisfied many problems may occur by Phuld. This process is called Kalaha Wayegu after which the bride starts Khayegu (crying).

\section{Khwaya-Gue-Kaye-gu}

After the finishing of the Thayaebhu nakegu ritual, Khwaya-Gue-Kaye-gu starts. For the performance of this ritual, groom's mother gives a Dhau Sagun and Sagunpispa to the bride. Sagunpuspa is a type of cloth made by silk and golden wire called Taas. The groom's party offers the areca nuts to the bride's family members and for the kin deity of the bride. Lord Ganesh is also greeted by the nuts. In this ritual family members and kin relatives also receive the nuts by the bride's hand, called-Gue-Kaye-Gue. Bride gives nuts starting from the youngest member to the old one and her parents receive at the last. The nuts are specially prepared as Pulugue, which contains four areca nuts in small bag of red colored cloth. In return of this as blessing every family member give the Kosa (present) to the bride. The symbolic meaning of this ritual is that it is the time of see-off and departure of the bride from her natal home.

The see off ceremony of the bride is very emotional time for her, parents and relatives of the bride. After finishing of the Gue-Kaye-Gu ritual, Nini or sister holds the bride's hand and asks to stand up for the process. Then bride's uncle or elder brother carries her in his back to put her on Doo (hammock) and the groom's father covers the Doo with a shawl, known as Doophanga Fayekegu. Then the Doo (hammock) with bride is lifted by the Dulhya Bhalya (hammock carriers). The procession members slowly start to move to the groom's house with bride. According to the tradition the bride is accompanied by her friend, consisting a Samuli (bride's maid) and Lami to groom's house. While the procession is returning to the groom's house groom's mother holds a Khwata with worship materials and the Lami holds the burning Sukunda. Musical party also should have big burning Sukunda.

According to the tradition it is not necessary that the groom should present in the procession because the core wedding rituals are performed in the groom's house. But among the other Newar communities like Shrestha groom must proceed in the marriage procession. Groom's father performs significant role in Maharjan marriage system. He performs the Doophanga fayegu ritual. By tradition groom's father should wear Bhulayuga during the marriage ritual. 
The procession, before reaching at the groom's house, near the Ganesh temple a ritual of conversation takes place. The priests of both sides and elders participate in this function. The members of the bride's party recite that she has been taken care like a delicate flower; she does not know many things about life and can make mistakes. So we humbly request to excuse for her mistakes. Then the bridegroom's party assures to take care of the bride like in her natal home. This is also a ritual of formality. After the finishing of the conversation both the bride and groom's party exchange a bundle of burning bamboo sticks, which is called Mi-pwa hilegu (change of fire). Then the procession moves on. The Kosa (dowry) is also sent with the bride. Traditional Newari dowry consists of big wooden box known as Sanusa, cooking utensils, plates, cups, Gagro (water vessel), bedpan, Phengu (spinning wheel), Sukn (straw mat), and Dhiki (wicker tray). The maternal uncle gives a goat as a Kosa to the bride.

In bridegroom's side eldest female members (Thkalinaki) and second eldest female member (Nokunaki) wait at the main gate of the house for La-Sa-Kusa (welcome) of the bride and groom. For the welcome ceremony the gate should be washed with cow dung and decorated with different auspicious objects.

\section{La-Sa-Kusa (welcome) ritual}

When the groom's procession reaches to the entrance of the bridegroom's house, the groom's family performs La-Sa-Kusa and receives the bride as Laxmi (goddess of wealth) (Shrestha \& Singh, 1987). Then the priest starts to worship Lord Ganesh and kin deity of the bridegroom. After that, Thakalinaku proceeds to give a ritual welcome to the bride with burning soaks in the ghee. Then the groom's mother washes the bride's feet with red colored holy water and throws rice and Eeka, Poka (mustard seed) everywhere to satisfy the evil spirits. The Thakalinaki performs Arati of the bride and showers with rice, flowers and pieces of fruits over her. Then the Thakalinaki performs the ritual of Shipaha or Pathi Luigu. The Pathi is fully filled three times with flowers and fruit pieces and showers three times over the bride. Then the Thakalinaki puts Tika on the bride's forehead. In the mean time the groom's mother holds the Kwata and curd. One woman sweeps the floor, other women pours water on the way and takes the bride inside the house by catching a key, which symbolizes that from that day the bride is allowed to use all belongings of the house as her own.

After the finishing of the La-Sa-Kusa, Gue-Sa-Yekue-Gu ritual takes place. In this ritual the Lami gives the four pieces of areca nuts to the bride, which are brought from the bride's house. Then the bride offers the areca nuts to the groom's kin deity for greeting them and family members. This ritual is as same as performed in the bride's house. Then she gives the areca nut to her groom and parents-in-law. And she gives Putu Gue to her 
parent in-law at the last, while giving the Putu Gu bride has to bow down in front of all elderly members of the groom's family. All those who receive the areca nuts from the bride are required to give some money, at least a coin, to the bride as a token of gift. This is the ritual of introduction of bride with her new family members.

After the finishing of the Gue-Sa-Yekue-Gu the Honkegu ritual is performed. This is also a most significant ritual of the marriage procedure. It is performed in an auspicious day preferred by an astrologer. This is the worshipping ceremony of the kin deity of groom and Lord Ganesh. When the worship is finished the Thakalinaki puts Tika on forehead of groom and bride along with other family members. Thayabhu Nakegu ritual is performed after the finishing of the Honkegu ritual, which is also known as Sahjanho Nakegu. It is the ceremony of feeding the ritual food to the groom and bride. The new couple eats the ritual food together in Thayabhu. First of all the groom offers some food to the god from the Thayabhu then he eats or he makes the food polluted and leaves for his bride which is then taken by the bride as ritual.

The younger member of the family throws the rest of the food of Thayabhu at the Chhawas by a younger member of the Phuki. This is same as performed in the bride's house. But it is a custom that the person who throws the food in Chhawas should not look back. This is usually emphasized as Hindu's wedding, which includes a similar ritual. In this respect Bennett (1983) explains that among the caste Hindu "the groom takes a bite of the food, thus making it Jutho or ritually polluted, and the bride must finish it". The Jutho Khane (eating of polluted food of groom) ritual reflects "the bride's subservient status and respect for her husband" (ibid).

In the bridegroom's house marriage feast is arranged for three days. Guests are separated in three agnates groups close relatives, friends of the family and others. One day before the proper wedding day groom and bride's father perform a most important ritual called Shraddha to greet their ancestors with the help of their own priest. Next day is proper wedding day and a grand party is arranged in the evening known as Mu Bhoya (main party) or Biha Bhoya. The whole family members of the close relatives are invited called Bhochipan who were present until the whole wedding rituals are over.

On the same day they celebrate Hinu Bhoya before the main feast, only the members of their own Diwali Guthi should attend Hinu Bhoya. In the Hinu Bhoya the bride must offer four areca nuts to Hinu Phuki. After receiving areca nuts, Hinu Phuki should give some money to the bride as blessings. Without completing Hinu Bhoya they cannot proceed to the main feast.

If a boy and girl eloped they only perform Swayambar with the girl. During Swayambar they invite Hinu Phuki for Hinu Bhoya within a year. If the ritual of offering the areca 
nuts to the Hinu Phuki is not performed they are not allowed to celebrateHinu Bhoya. The bride is also not allowed to enter in the bridegroom's Diga Dyah Puja.

\section{Khwan Puja}

In the afternoon of the main feast day Khwan Puja Wanegu ritual is performed. In this ritual the drummer group, Lami, groom's sisters, groom, bride and Samuli go to the local deity Kwana Gane in Natole (a Tole of Patan) along with some other elders. The groom's parents worship and greet the deity and then the groom puts the vermillion powder on the forehead of the bride known as Sincha-chha yakegu. Then the bride bows down to touch groom's feet by her forehead (Pha. Bhakhi Yegu) for three times to greet him. After this ritual all the participants return to groom's home. Then the new couple greets the lineage deity in the groom's home and visit local Ganesh temple. The new couple offers rice, flowers, incense, and ritual foods together in a banana leaf plate. They also worship the Pancharatna (five metals), Pancha Dhatu symbolized by some metal placed in front of them. They exchange handful of rice and the five metals power thrice. Then the boy puts a Tika in his bride's forehead (Toffin, 2007). After the performance of this ritual they enjoy a small feast near the temple side.

\section{Paju Bicha and Khwa-Swa-Gu}

Maternal uncle and Lami visit the groom's house with sugarcane, Bayal (cherry), Satu Bayal (small cherry), green peas and fresh fruits. It is to know how the bride is.

The Khwa-Swa-Gu ceremony performed at groom's home for a small reception in the same evening. The bride's mother, her close relatives and friends come to visit the bride. It is because of their concern for their daughter. The bride's party visits with a bundle of sugarcane. All members who visit the bride including her family members give some money according to their capacity. After the performance of this ritual bride's party are treated with ceremonial food.

\section{Chyanu Bicha}

This ritual takes place after the main feast of the marriage.Eight people of the bride's family including mother, father, brother, maternal uncle and auntie, Lami and other family members visit the groom's house to with concern of their newly married daughter. They take sari, Kwata, Sagun, four kilograms of beaten rice and husked rice with them for the groom's family. This ritual named as such because eight people with eight kilogram of Chiura and rice visit the bride. In Newari language Chyanu means number eight and Bicha means concern. The next day, at the Chyanu Bicha ritual bride's mother and the 
Lami bring the beaten rice five kilogram, Manachhoyal one kilogram, two liters of home made liquor, "Wo" twelve pieces with them and visit the groom's house. And they enjoy Tuchha and feast together with groom's side.

\section{Samadhi Swaku and Dilaja Duchakeju}

Duchayekeju ritual is performed few days after wedding as per the both families convenience. For this ritual the groom and some of his friends go to the bride's house with the Lami. According to the ritual the Lami handover the areca nuts to the bridegroom to offer the kin deity. After that he distributes four areca nuts to the bride's every members of the family. All family members who receive the areca nuts from the groom should give some money as Dakshina to the groom. After finishing of this ritual they again perform Sagun ritual. In Sagun ritual, bride's mother put the Tika on the groom and bride's forehead then give them some money as Dakshina and a pair of clothes as a part of the gift. Then bride, groom, Lami, other guests and family members enjoy the food together. When they finish the function groom and bride return to the groom's house with Lami and other participants. When they go to groom's home bride's parents send some $K u$ with their daughter. $K u$ means different foodstuffs, which contains beaten rice- three kilogram, $\mathrm{Wa}$-lentil piece twenty pieces, boiled egg-twenty pieces, homemade liquor- one liter. Only after this ritual the bride and groom are allowed to sleep together in his room. Since the performance of this ritual the groom is free to visit his in-laws home anytime.

\section{Suwa and Ku Paha (thanks giving)}

Thereafter Dilaja Duchakeju ritual and Ku Paha is performed. Ku Paha means thanks giving to all the relatives and friends who helped to perform the marriage ceremony successfully. For the Ku Paha function bridegroom's parents invite all the relatives and friends. First of all guests are welcomed by the offerings of Tuchha then enjoy dinner at night. Both the bride and groom's side perform this ritual respectively. After finishing of this ritual the marriage ceremony is formally over.

\section{Conclusion}

In this exploration more detailed account of the traditional marriage process and practices among the Maharjan people is presented very elaborately. The processes and their various dimensions were elaborated clearly. This research traced out clear-cut notion about traditional marriage practices and its various components according to their priority. Like in other traditions the principal objective of marriage is considered to be procreation of children and to fulfillment of biological needs of an individual. The Maharjan marriage composes of various functions with symbolic meanings, which is mainly patrilocal in 
nature. The pre wedding rituals like Bel-Vivah (Ihi) is described where every girl is entitled to be married to a fruit-Bel ideally before her puberty sets in earlier to getting married to a man. Also the role of Lami has been described in detail giving a picture of how it plays a key role in the search of an ideal partner, fixing a marriage and its conduction.

Subsequently other rituals like Lakha Biyegu signifying good luck for the bride, Painaja the farewell ritual, Paju ku Ritual, Payanbiya Bhoya, Hinu Bhoya and La-So-Wanegu the marriage procession is observed. The Proper Wedding ritual follows this; Thayaebhu Nakegu also called Chaurasi byanjan, Khwaya-Gue-Kaye-gu, La-Sa-Kusa (welcome) ritual, Khwan Puja, Paju Bicha and Khwa-Swa-Gu that are described above. The marriage ends by performing the Suwa and Ku Paha (thanks giving) to all the members involved in the wedding ceremony. This plot highlights the rich cultural practices of the Maharjans based on their beliefs and tradition. It is intended in bringing to limelight the inviolability and beauty of the marriage observed in the Majarjan community of Nepal.

\section{References}

Acharya, B. R. (1972). "Questions and answers" in P. R. Sharma (ed.). B. R. Acharya and His Works. Kathmandu: Centre for Nepal and Asian Studies (CNAS), Tribhuvan University, Nepal.

Bennett, Lynn. (1983). "Dangerous wives and sacred sisters: Social and symbolic roles of high-caste women in Nepal". New York: Columbia University Press, USA.

Bista, D. B. (1996). People of Nepal (6 $6^{\text {th }}$ Edition). Kathmandu: Ratna Pustak Bhandar, Nepal.

Furer-Haimendorf, C. V. (1956). Elements of Newar social structure. Journal of the Royal Anthropological Institute, 86, 15-38. Royal Anthropological Institute of Great Britain and Ireland.

Gellner, D. N. (1992). Monk, householder, and Tantric Priest: Newar Buddhism and its Hierarchy of Ritual. Cambridge University Press.

Lowie, R. H. (1961). Social organization ( $3^{\text {rd }}$ Edition). London: Rutledge \& Kegan, Paul Ltd. Broadway House, United Kingdom.

Nepali, G. S. (1965). The Newars: An ethno-sociological study of a himalayan community. Bombay: United Asia Publications, India.

Rao, S. C. N. (2004). Sociology: Primary principles. New Delhi: S. Chand and Company Ltd., India.

Regmi, D. R. (1952). Ancient and medieval Nepal. Calcutta: Mukhopadhyay, India.

Rosser, C. (1966). Social mobility in the Newar caste system, caste and kin in Nepal, India and Ceylon: Anthropological Studies in Hindu-Buddhist Contact Zones. London and The Hague: East-West Publications.

Shakya, A. M. (2000). Newar marriage and kinship in Kathmandu, Nepal. (Unpublished doctoral dissertation). Department of Human Sciences, Brunel University, United Kingdom.

Toffin, G. (2007). Newar society: City, village and periphery. Kathmandu: Baha Himal Books, Nepal. 